\title{
Immunological induction with thymoglobulin: reduction in the number of doses in renal transplant from deceased donor
}

\author{
Indução imunológica com timoglobulina: redução no número de doses em transplante de rim \\ com doador falecido
}

\author{
Lucio Roberto Requião Moura ${ }^{1}$, Eduardo José Tonato ${ }^{1}$, Érika Arruda Ferraz, Thiago Corsi Filliponi ${ }^{1}$, Rogério \\ Chinen $^{1}$, Ana Cristina Carvalho Matos ${ }^{1}$, Maurício Rodrigues Fregonesi da Silva ${ }^{1}$, Marcelino de Souza Durão ${ }^{1}$, \\ Alvaro Pacheco-Silva ${ }^{1}$
}

\begin{abstract}
Objective: To compare three different regimens of thymoglobulin induction. Methods: One hundred seventy two patients submitted to renal transplantation from a dead donor were divided into three groups according to the total number of thymoglobulin doses used in the post-transplantation surgery: Group 1, until 14 doses - May 2002 to June $2004(n=48)$; Group 2, until 7 doses - July 2004 to December $2006(n=57)$; Group 3, until 4 doses - January 2007 to July 2009 ( $n=67)$. The three groups were compared according to the main outcomes. Results: The main demographic differences among the groups were: greater dialysis time in Group $3(p<0.001$ for Group 1; and $p=0.04$ for Group 2); donor age, greater in Groups 2 and 3 ( $p=0.02 ; p=0.01$, respectively); and cold ischemia time progressively greater from Group 1 to $3: 19.5 \pm 5.1$ to $24.6 \pm 5.7$ hours $(p<0.001)$. In relation to the inhibitor of calcineurin, the relation Tac/Csa was 14.6/66.7\% in Group 1, 78.9/12.3\% in Group 2 and $100 / 0 \%$ in Group 3. Reflecting the increase in cold ischemia time, the incidence of delayed graft function was $64.6 \%, 68.4 \%$ e $82.1 \%$ in Groups 1, 2 and 3, respectively ( $p=n s)$. The incidence of acute rejection was similar in the three groups: $16.7 \%$ (1); $16.3 \%$ (2) and $16.4(3)-p=n s$. The prevalence of viremia for cytomegalovirus was $61.7 \%$ in Group 1, 66.1\% in Group 2 and $83.3 \%$ in Group $3(p=n s)$. There were no difference related to the number of infected cells with cytomegalovirus in antigenemia, according to the groups, however, patients in Group 3 had an earlier diagnosis: from $64.3 \pm 28.5$ days in Grup 2, to $47.1 \pm 22.5$ days, in Group 3, $p<0.001$. Survival of the graft in one year was $89.6 \%, 92.9 \%$ and $91.0 \%$, in Groups 1, 2 and 3, respectively $(p=n s)$. The graft function was much better with the lower doses of thymoglobulin: Group 1: $57.0 \pm 20.0 \mathrm{~mL} / \mathrm{min}$; Group 2: $67.0 \pm 18.4 \mathrm{~mL} / \mathrm{min}(p=0.008)$; Group 3: $71.2 \pm 18.4 \mathrm{~mL} / \mathrm{min}$ ( $\mathrm{p}<0.001$, Group 1 versus Group 3; $\mathrm{p}=0.06$, Group 1 versus Group 2). There was a significant reduction in the costs of induction protocol from $\cup \$ 7,567.02$ to $\cup \$ 3,485.56(p<0.001)$. Conclusions: The total number of thymoglobulin doses for immunologic induction could be reduced in a safe and effective way, without a negative im-
\end{abstract}

pact in graft rejection or survival, preserving renal function and being significantly cheaper.

Keywords: Antibodies/administration \& dosage; Immune system/ drug effects; Graft rejection; Survival

\section{RESUMO}

Objetivo: Comparar três regimes diferentes de indução com timoglobulina. Métodos: Cento e setenta e dois pacientes submetidos a transplante de rim com doador falecido foram divididos em três grupos, de acordo com o número total de doses de timoglobulina utilizada no pós-operatório: Grupo 1, até 14 doses - Maio de 2002 a Junho de $2004(\mathrm{n}=48)$; Grupo 2, até 7 doses - Julho de 2004 a Dezembro de $2006(n=57)$; Grupo 3, até 4 doses - Janeiro de 2007 a Julho de 2009 ( $n=67)$. Os três grupos foram comparados de acordo com os principais desfechos. Resultados: As principais diferenças demográficas entre os três grupos foram: tempo em diálise, que foi maior no Grupo 3 ( $p<0,001$ para 0 Grupo 1; $p=0,04$ para o Grupo 2); idade do doador, maior nos Grupos 2 e 3 ( $p=0,02 ; p=0,01$, respectivamente); e o tempo de isquemia fria, progressivamente maior do Grupo 1 ao 3: 19,5 $\pm 5,1$ para 24,6 $\pm 5,7$ horas $(p<0,001)$. Em relação ao inibidor de calcineurina utilizado, a relação entre Tac/Csa foi de $14,6 / 66,7 \%$ no Grupo $1,78,9 / 12,3 \%$ no Grupo 2 e de 100/0\% no Grupo 3. Refletindo o aumento no tempo de isquemia fria, a incidência de delayed graft function foi de $64,6 \%, 68,4 \%$ e $82,1 \%$ nos Grupos 1,2 e 3 , respectivamente $(p=n s)$. A incidência de rejeição aguda foi semelhante nos três grupos: $16,7 \%$ (1), 16,3\% (2) e 16,4\% (3) - p $=$ ns. A prevalência de viremia para citomegalovírus foi de $61.7 \%$ no Grupo 1; 66,1\% no Grupo 2; e 83,3\% no Grupo 3 ( $p=$ ns). Não houve diferenças quanto ao número de células infectadas com o citomegalovírus na antigenemia, de acordo com os grupos; entretanto, os pacientes do Grupo 3 tiveram diagnóstico mais precoce: de 64,3 \pm 28,5 dias no Grupo 2, para 47,1 $\pm 22,5$ dias no Grupo $3(p<0,001)$. A sobrevida do enxerto em um ano foi de $89,6 \%, 92,9 \%$ e $91,0 \%$, nos Grupos 1, 2 e 3, respectivamente ( $p=n s)$. A função do enxerto foi substancialmente melhor com menor número de doses de timoglobu-

\footnotetext{
Study carried out at Transplant Service - Hospital Israelita Albert Einstein - H.A.E. - São Paulo (SP), Brazil.

' Hospital Israelita Albert Einstein - HIAE - Sao Paulo (SP), Brazil.

Corresponding author: Lucio Roberto Requião Moura - Rua Agostinho Gomes, 1326, Ap 1062 - Ipiranga - CEP 04206000 - Sao Paulo (SP), Brasil - Tel.: $119577-1568$ - e-mail: Irequiao@einstein.br

Received: Jul 31, 2010 - Accepted: Jan 24, 2011

* Conflict of interests: none.
} 
lina: Grupo 1: $57,0 \pm 20,0 \mathrm{~mL} / \mathrm{min} ;$ Grupo 2: 67,0 \pm 18,4 mL/min $(\mathrm{p}$ $=0,008)$; Grupo 3: 71,2 $\pm 18,4 \mathrm{~mL} / \mathrm{min}(\mathrm{p}<0,001$, Grupo 1 versus Grupo 3; $p=0,06$, Grupo 1 versus Grupo 2). Houve uma redução significativa no custo do protocolo de indução de U\$ 7.567,02 para U\$ 3.485,56 ( $p<0,001$ ). Conclusão: 0 número total de doses de timoglobulina para indução imunológica pôde ser reduzido de forma segura e eficaz, sem impacto negativo na incidência de rejeição ou sobrevida do enxerto, com preservação da função renal, sendo significativamente mais barato.

Descritores: Anticorpos/administração \& dosagem; Sistema imunológico/efeito de drogas; Rejeição de enxerto; Sobrevida

\section{INTRODUCTION}

Human anti-lymphocyte antibodies have been used ever since the 1960's in organ and tissue transplantations ${ }^{(1)}$. Initially, these preparations were indicated for the conditioning of bone marrow receptors, treatment of graft versus host disease and acute rejection (AR). Recently, they have played a major role in prophylaxis of AR, especially in kidney transplantations ${ }^{(2)}$. The use of lymphocytedepleting antibodies with the purpose of reducing immunological events is known as immunological induction and is indicated in high-risk receptors ${ }^{(3)}$.

Besides AR, another early event in kidney transplantation with a negative impact on the evolution of the graft is ischemia-reperfusion injury (IRI), which is clinically characterized by delayed graft function (DGF) ${ }^{(4,5)}$. Patients with DGF are at increased risk for AR because, after reperfusion, an up-regulation of immunogenic molecules and an increase in HLA molecule expression occurs on the surface of the renal tissue cells ${ }^{(6,7)}$. It has already been demonstrated that DGF and AR interfere in the prognosis of the graft, so that patients who are more susceptible to the effects of IRI are, per se, considered at high immunological risk ${ }^{(8)}$. Current knowledge about the pathophysiology of IRI shows that the immune system, especially lymphocyte CD4+, is fundamental for the occurrence of the injury, and that the lymphocyte surface molecules with cell activation, endothelial adhesion and migration to the site of the injury functions play an essential part in this process ${ }^{(9)}$. Polyclonal antilymphocyte antibodies are capable of blocking these molecules, besides promoting intense lymphopenia, which significantly reduces the effects of IRI ${ }^{(10)}$. Thus, the objectives of immunological induction with polyclonal antibodies are to reduce the risk of $A R$ and to attenuate the effects of IRI.

Currently, about $70 \%$ of the kidney transplant recipients are under some kind of induction therapy, either with thymoglobulin, a human antithymocyte globulin produced from rabbit serum, which is a powerful lymphocyte-depleting polyclonal antibody that targets the multiple immunological epitopes, or with non-lymphocyte-depleting monoclonal antibodies $^{(2)}$, such as basilixmab or daclizumab, which target the interleukin-2 receptor ${ }^{(11)}$. The use of immunological induction with thymoglobulin is related with a reduction in the incidence of $A R$ and $\mathrm{DGF}^{(12)}$.

Historically, different protocols with intravenous doses varying from 7 to 14 days have been described ${ }^{(12)}$. Recently, a study comparing a short, three-day treatment with thymoglobulin with a historical control that used a greater number of doses demonstrated that the short treatment was as effective and safe as the longer one, besides reducing the post-transplantation hospital stay ${ }^{(13)}$. The current protocols focus mainly on an accumulated dose, using varying frequencies and administration times, and there is even a protocol with a single $5.0 \mathrm{mg} / \mathrm{kg}$ dose, shown to be able to produce an intense and lasting lymphopenia and to be as effective as all the others ${ }^{(14)}$.

\section{OBJECTIVE}

The aim of the study was to compare three different thymoglobulin immunological induction regimens in renal transplant from deceased donors.

\section{METHODS}

This research was designed as a monocentric, prospective, non-randomized and non-blind study, with renal transplants from deceased donors, using three historical groups which employed an intraoperative dose of thymoglobulin followed by sequential doses, based on the circulating CD3 + lymphocyte count. The outcomes evaluated were graft survival, prevalence of DGF, AR and cytomegalovírus (CMV) infection, besides the renal graft function a year after the transplantation.

\section{Study population}

This is a longitudinal, observational study on a historical cohort, including all patients who underwent cadaveric renal transplantation at the Hospital Israelita Albert Einstein from May 2002 through July 2009. Data collection was carried out in July 2010, so that all patients enrolled had at least a one-year follow-up.

Two distinct populations were considered (Figure $1)$ : initially, all patients submitted to a cadaveric renal transplantation $(\mathrm{n}=186)$, but, for the analysis of the number of thymoglobulin doses, patients who 


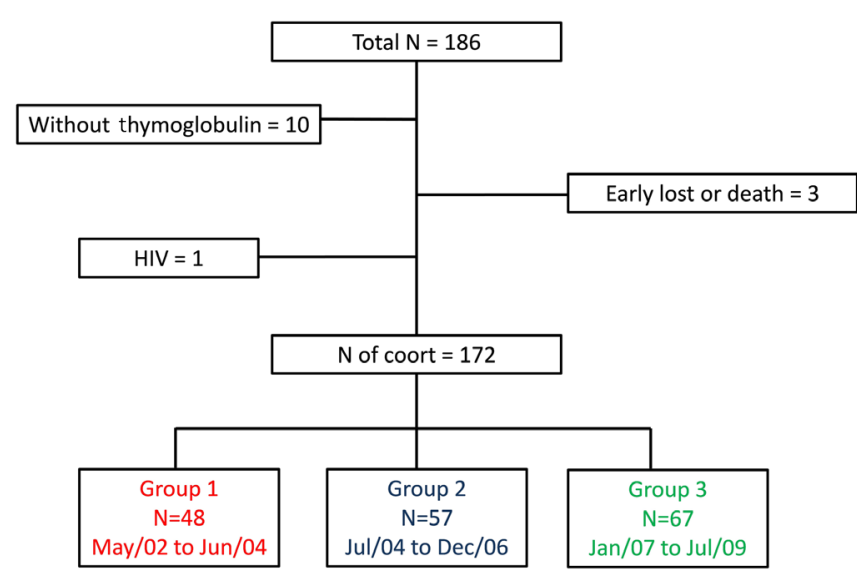

Figure 1. Population distribution according to the induction protocol used. Group 1 - up to 14 doses of thymoglobulin, and the main calcineurin inhibitor was cyclosporin; Group 2 - up to 7 doses, and the main calcineurin inhibitor was tacrolimus; Group 3 - up to 4 doses, and the only calcineurin inhibitor was tacrolimus

progressed toward loss of the renal graft or early death (still hospitalized for the transplantation), as well as those who could not receive the induction protocol under study $(\mathrm{n}=14)$ were excluded.

\section{Immunological induction and immunosuppression protocol}

Immunological induction with thymoglobulin is used according to protocol for all patients submitted to a cadaveric renal transplantation in the service where the study was conducted. The induction protocol consists of one intraoperative Thymoglobulin ${ }^{\circledR}$ dose of $1.5 \mathrm{mg} / \mathrm{kg}$, followed by sequential doses of $1.0 \mathrm{mg} / \mathrm{kg}$, according to the circulating CD3 + lymphocyte count, done by flow cytometry, and indicated whenever the CD3+ count exceeds 20 cells $^{(15,16)}$.

The antibody was administered by slow continuous infusion, during 6 hours, by central line or arteriovenous fistula, and 30 minutes after one $0.5 \mathrm{mg} / \mathrm{kg}$ dose of SoluMedrol, dipirone and diphenhydramine. The total amount of thymoglobulin doses used in the protocol varied according to the time when the transplantation was performed. Immunosuppression was completed with mycophenolate and a calcineurin inhibitor, the latter being introduced only after the last dose of antibody, provided the CD3 + count was higher than 20 cells. The calcineurin inhibitors were cyclosporin or tacrolimus. The calcineurin inhibitor dose was adjusted according to the serum level, and that of mycophenolate according to the side effects (diarrhea or leucopenia). All patients received prophylaxis with albendazol for 5 days after the transplantation and with sulfamethoxazole trimethoprim up to 6 months from the transplantation.

\section{Division of groups according to total number of thymoglobulin doses}

During the period going from May 2002 to June 2004, the induction protocol consisted of a maximum of 14 doses of thymoglobulin, being interrupted earlier if the patient recovered graft function: urine volume higher than $2.0 \mathrm{~L} /$ day and/or serum creatinine lower than $5.0 \mathrm{mg} / \mathrm{dL}$. During this period, 48 patients who received $9.0 \pm 3.8$ doses of thymoglobulin on average were enrolled. An analysis of the results obtained with this protocol was published, showing that patients who received up to 7 doses of the antibody progressed in a similar way to those who received more than 7 doses; therefore, from July 2004 through December 2006, the maximum amount of thymoglobulin doses was reduced from 14 to 7 . During this second period, 57 patients were enrolled and received, in average, $4.9 \pm 1.5$ doses of the antibody. Based on the results obtained by other studies, as from January 2007, the maximum number of doses was further reduced from 7 to 4, and the antibody administration was discontinued after the fourth dose, regardless of the recovery of the renal graft function. During this third period, 67 transplantations were performed and an average of $3.9 \pm 0.8$ doses was used. Seven patients received more than 4 doses, due to specific indications of the assisting team: five patients received 5 doses, and two patients received 6 doses. These patients were not excluded from Group 3 because, although they received more than 4 doses, they did not receive all 7 doses of the patients in the second period. For the purposes of analysis and comparison, the patients who underwent transplantations during the first period were included in Group 1, those of the second period in Group 2, and those of the third period in Group 3 (Figure 1).

\section{Definitions and outcomes}

DGF was considered whenever patients needed dialysis in the first week after transplantation. Patients with persisting DGF after one week were submitted to a renal graft biopsy. The AR diagnoses were all confirmed by graft biopsy, according to the Banff classification in force at the time of the transplantation. Biopsies which did not meet the criteria defining AR, but displayed borderline alterations (borderline rejection) were also considered as acute rejection.

The strategy adopted to reduce the risk of CMV infection was a preemptive treatment. Thus, all patients were followed-up with a regular CMV viremia test between 30 and 90 days after transplantation. Viremia was detected by antigenemia, using immunofluorescence 
for the pp65 antigen ${ }^{(17)}$. Treatment with ganciclovir was indicated in patients with antigenemia above 4 cells or in patients with antigenemia below 4 cells but with symptoms or altered laboratory findings defining CMV infection considered as acute.

Initially the outcomes in the whole population of transplanted patients $(n=186)$ were evaluated: graft loss, defined as a return to dialysis; death; accumulated incidence of $\mathrm{AR}$ in the first year after transplantation; CMV infection and renal graft survival over the first year after transplantation, not censored for deaths. Among patients divided into groups according to the number of thymoglobulin doses used, the evaluated outcomes were: prevalence of DGF, AR and CMV; survival of the renal graft after a one-year follow-up, not censored for deaths; renal graft function, estimated by calculating creatinine clearance by means of the Cockroft-Gault formula.

The thymoglobulin cost was estimated based on the number of vials used for each patient, where the accumulated dose coefficient was calculated based on the $25 \mathrm{mg}$ dose per vial. The value per thymoglobulin vial used in this study was recorded in US dollars, as the institution charges for it.

\section{Statistical analysis}

The numerical variables were summarized as mean and standard deviation, added by the median, with a variation from the minimum to the maximum value if the distribution of the values followed a non-normal pattern. In presentation of results, the medians were described following the means as follows: (med- [Min - Max]). The categorical variables were summarized as frequencies and presented as percentages. The numerical variables were compared using Student's $t$ test or the U-Mann-Whitney test, for normal and nonnormal distributions, respectively. The categorical variables were compared using the chi-square $\left(\chi^{2}\right)$ or Fischer's exact test, according to the number of events on a $2 \times 2$ table. The accumulated incidence of AR and CMV and graft survival were calculated using KaplanMeier actuarial method and compared by means of the Wilkoxon and Tarone-Ware tests. A database with all pieces of patient's information was constructed in Excel 2007, and the statistical analysis was made using the Statistical Package for Social Science (SPSS), both for Windows. For statistical significance, the value considered was $\mathrm{p}<0.05$, with a $95 \%$ confidence interval.

This study was conducted as a partial analysis of the project entitled "Functional and Morphological Impact of Cytomegalovirus Infection in Renal Grafts", approved by the Research Ethics Committee of the Hospital Israelita Albert Einstein.

\section{RESULTS}

\section{Results concerning the general population of the study}

From May 2002 through July 2009, 186 cadaveric renal transplantations were performed, with a mean followup time of $42.9 \pm 26.8$ months. Of these patients, $6.4 \%$ $(12 / 186)$ progressed with graft loss within a mean time of $16.6 \pm 23.2$ months (med-9.6 [0-79.5]), and $8.6 \%(16 / 186)$ died within a mean time of $14.0 \pm 16.3$ months (med-9.0 [0-44.5]). The accumulated incidence of AR after one year from transplantation was $15.9 \%$ (Figure 2A), and of CMV infection $73.2 \%$ (Figure 2B). In this cohort, graft survival after one year from transplantation, not censored for deaths, was $90.3 \%$ (Figure 2C).

\section{Demographic data of patients enrolled by groups, according to the induction protocol}

The main variables, according to the group under study, are presented in Table 1 . The patients who underwent transplantation more recently (Group 3) were of younger age than those in the other groups, but the difference was not significant. The time on a waiting list increased significantly, form $34.3 \pm 26.2$ months (med-25 [0-93]) in Group 1 to $55.6 \pm 48.2$ months (med-39 [1-237]) in Group 2 ( $\mathrm{p}=0.02$, Group 1 versus Group 2 ), and was $67.3 \pm 42.3$ months (med60 [6-209]) in Group 3 ( $\mathrm{p}<0.001$, Group 1 versus 3; $\mathrm{p}=0.04$, Group 3 versus Group 2).

Similarly, there was a significant increase in cold ischemia time (CIT) over the evaluated period (Figure 3A). In Group 1 patients, the mean CIT was of 19.5 \pm 5.1 hours, while in those of Group 2 it was $21.6 \pm$ 6.3 hours ( $\mathrm{p}=0.07$, Group 1 versus Group 2), and in those of Group 3 it was $24.6 \pm 5.7$ hours $(\mathrm{p}<0.001$, Group 1 versus Group 3; $\mathrm{p}=0.002$, Group 2 versus Group 3). On the other hand, there was a significant reduction in the number of HLA mismatches: 3.2 \pm 1.2 in Group $1 ; 2.7 \pm 1.4$ in Group $2(\mathrm{p}=0.02$, Group 1 versus Group 2); $2.7 \pm 1.3$ in Group 3 ( $\mathrm{p}=$ 0.01 , Group 1 versus Group 3; $\mathrm{p}=\mathrm{ns}$, Group 2 versus Group 3).

In Group 1, $75 \%$ of the patients made use of cyclosporin as a calcineurin inhibitor and $14.6 \%$ made use of tacrolimus, while in Group 2 an inversion in the choice of the calcineurin inhibitor occurred; in that, $12.3 \%$ were on cyclosporin and $78.9 \%$ on tacrolimus ( $\mathrm{p}<0.001$, Group 1 versus Group 2). In Group 3, all patients used tacrolimus ( $\mathrm{p}<0.001$, Group 1 versus Group 3; $p=0.77$, Group 2 versus Group 3). In Groups 1 e 2 , respectively, $10.4 \%$ e $8.8 \%$ of patients used only two drugs or sirolimus instead of a calcineurin inhibitor. 


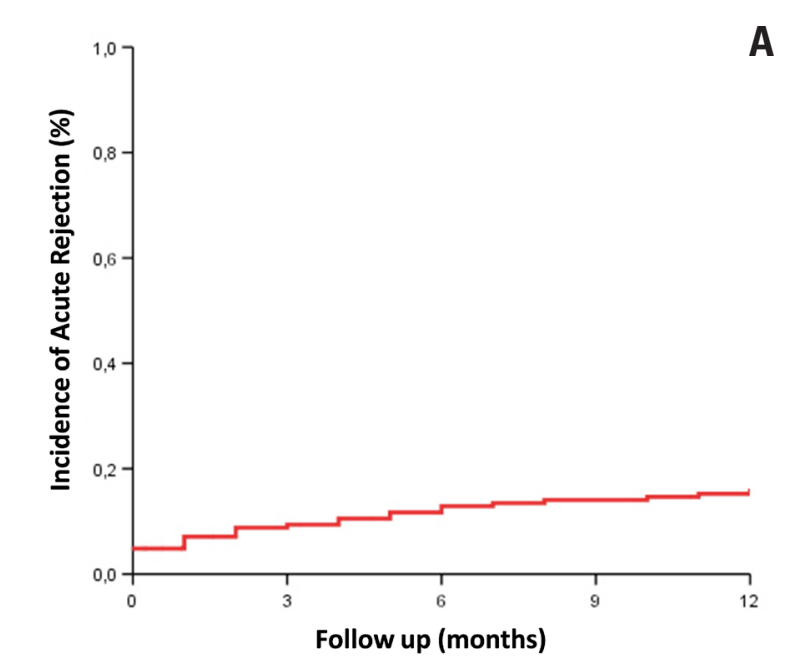

Incidence ( $\mathrm{N}$ at risk) $\quad 9.4(159) \quad 12.9(148) \quad 14.1(146) \quad 15.9(140)$

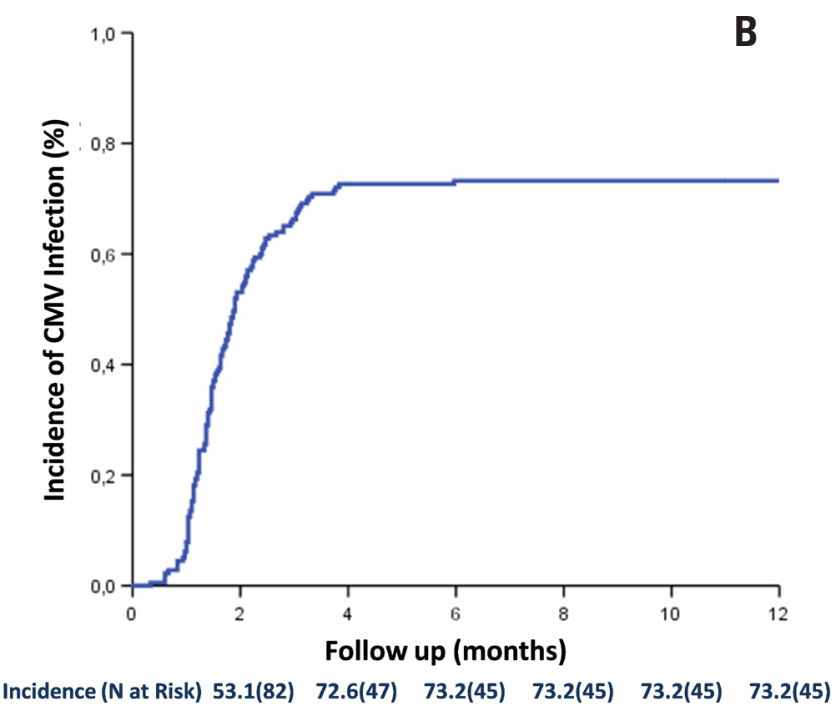

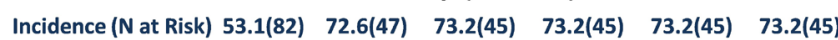

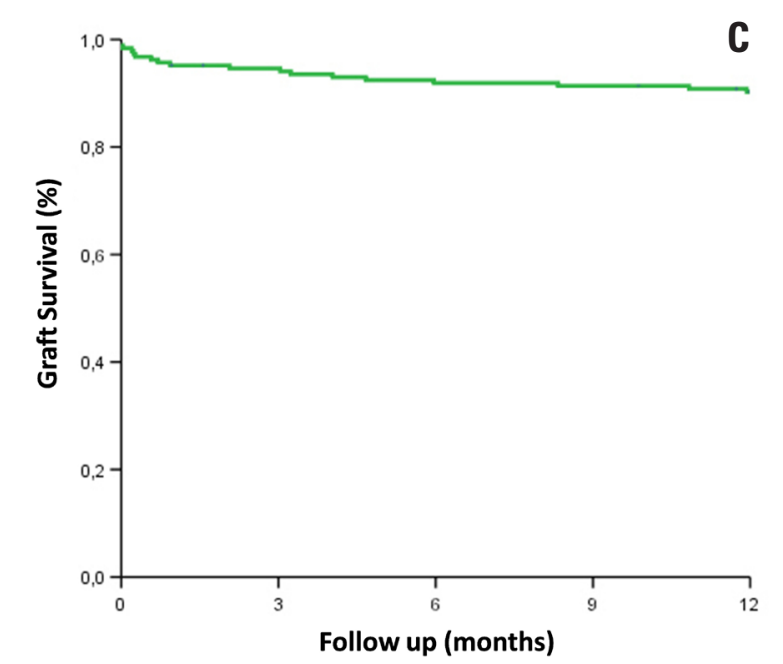

Incidence ( $\mathrm{N}$ at Risk) $\quad 94.6(174) \quad 91.9(169) \quad 91.4(168) \quad 90.3(163)$

Figure 2. A - Accumulated incidence of acute rejection throughout the first year of transplantation; B - Accumulated incidence of CMV infection throughout the first year of transplantation; $\mathrm{C}$ - Renal graft survival, not censored for death. Data related to total number of transplanted patients in the period $(N=196)$

\section{Complications after renal transplantation: DGF, AR and CIMV}

The main post-transplantation complication was DGF, which occurred in $72.7 \%$ of patients in this cohort. Along with the progressive increase of the CIT (Figure $3 \mathrm{~A}$ ), there was a $5.9 \%$ rise in the incidence of DGF from Group 1 to Group 2, going from $64.6 \%$ to $68.4 \%$, and of $17 \%$ from Group 1 to Group 3, in which it was $82.1 \%$ (Figure 3B). Despite this clinically significant increase, no statistically significant differences were found when the prevalence in the three groups was compared. And even though the CIT increased, there were no statistically significant differences in the time the patient remained on dialysis after transplantation: Group 1: $11.0 \pm 7.3$ days (med-19 [8-34]); Group 2: 12.6 \pm 8.5 days (med-20.5 [7-34.1]) ( $\mathrm{p}=0.38$, Group 1 versus Group 2); Group 3: $13.5 \pm 9.6$ days (med-23.8 [12.5-38]) ( $\mathrm{p}=0.19$, Group 1 versus Group 3; $\mathrm{p}=0.76$, Group 2 versus Group 3).

There were 33 episodes of AR, corresponding to a prevalence of $19.2 \%$; twenty-six of them occurred during the first year after transplantation, 16 of them in the first 3 months. There were no differences regarding the prevalence of $\mathrm{AR}$ in relation to the maximum amount of thymoglobulin doses used (Figure 4): $16.7 \%$ in Group 1; $16.3 \%$ in Group 2 ( $\mathrm{p}=0.99) ; 16.4 \%$ in Group 3 ( $\mathrm{p}=0.88$, Group 1 versus Group 3; $\mathrm{p}=0.88$, Group 2 versus Group 3). Taking into consideration only the AR episodes in the first year, once the objective of this analysis was the occurrence of adverse events in that period, it was observed that the reduction of the number of thymoglobulin doses produced a significant shortening of the time to occurrence of AR, which was earlier in patients submitted to the induction protocol with up to four doses: $139.9 \pm 135.6$ days (med-78 [10357]) in Group 1; $163.71 \pm 44.9$ (med-191 [7-298]) in Group $2(\mathrm{p}=0.05$, Group 1 versus Group 2); $44.9 \pm 49.3$ (med-18 [9-137]) no Group 3 ( $\mathrm{p}=0.08$, Group 1 versus Group 3; $\mathrm{p}=0.01$, Group 2 versus Group 3).

CMV infection was the main infectious complication, and positive antigenemia was detected, independently of clinical symptoms, in $68.7 \%$ of patients. There was a substantial increase in the prevalence of CMV in Group 3 compared to Groups 1 and 2. As shown in Figure 4, the prevalence of CMV in Group 1 was $61.7 \%$, while in Group 2 it was $66.1 \%$, and in Group $383.3 \%$. However, these differences are statistically not significant: $\mathrm{p}=0.85$, Group 1 versus Group 2; $\mathrm{p}=0.37$, Group 1 versus Group 3; $\mathrm{p}=0.48$, Group 2 versus Group 3. The viremia diagnosis, on the other hand, was made significantly earlier in Groups 2 and 3 compared to Group 1 (Figure 5A). In Group 1 , the CMV diagnosis was made after $64.3 \pm 28.5$ days 
Table 1. Demographic data per group of patients

\begin{tabular}{|c|c|c|c|}
\hline & Group 1 & Group 2 & Group 3 \\
\hline Variable & $n=48$ & $n=57$ & $n=67$ \\
\hline Age (years) & $43.7 \pm 14.1$ & $43.9 \pm 12.4$ & $46.3 \pm 13.5$ \\
\hline Gender (male) - \% & 60.4 & 54.4 & 50.7 \\
\hline Time in dialysis (months) & $34.3 \pm 26.2^{*}$ & $55.6 \pm 48.2^{*}$ & $67.3 \pm 42.3^{*}$ \\
\hline Donor age (years) & $34.8 \pm 12.9$ & $38.9 \pm 12.5$ & $39.2 \pm 13.8$ \\
\hline Donor gender (male) - \% & 66.7 & 40.4 & 54.5 \\
\hline Mismatches (number) & $3.2 \pm 1.2^{\dagger}$ & $2.7 \pm 1.4^{\dagger}$ & $2.7 \pm 1.3^{\dagger}$ \\
\hline CIT (hours) & $19.5 \pm 5.1^{\ddagger}$ & $21.6 \pm 6.3^{\ddagger}$ & $24.6 \pm 5.7^{\ddagger}$ \\
\hline Tac / Csa ( $\% / \%)$ & $14.6 / 75.0^{\#}$ & $78.9 / 12.3^{\#}$ & $100 / 0^{\#}$ \\
\hline
\end{tabular}

CIT: cold ischemia time; Tac: tacrolimus; Csa: cyclosporin

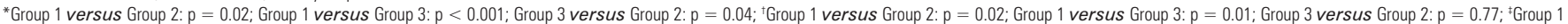
versus Group 2: $p=0.07$; Group 1 versus Group 3: $p<0.001$; Group 3 versus Group 2: $p=0.002 ;{ }^{*}$ Group 1 versus Group 2: $p<0.001 ;$ Group 1 versus Group 3: $p<0.001 ;$ Group 3 versus Group 2: $p=0.44$.
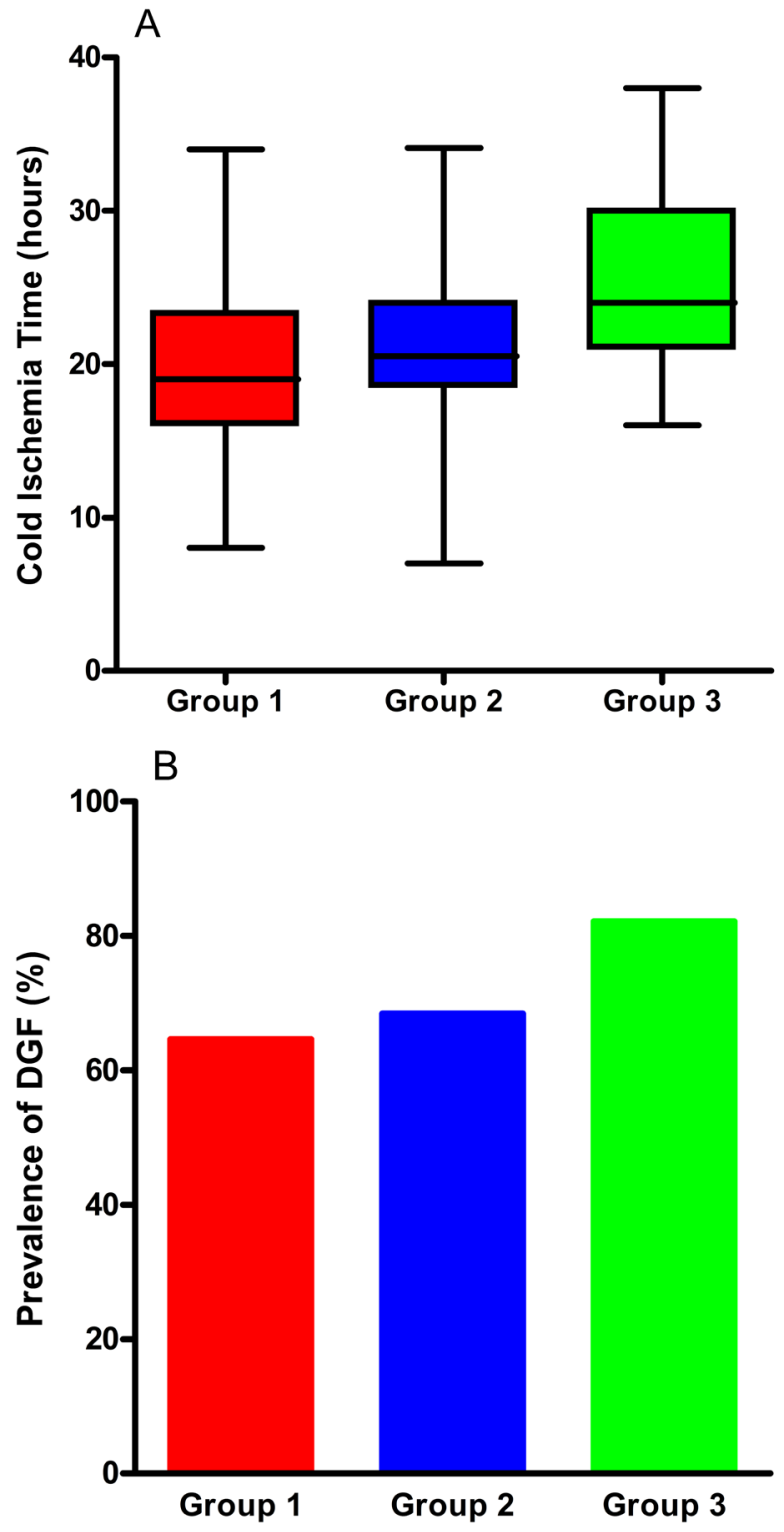

Figure 3. A - Range of cold ischemia time per group: Group 1- $19.5 \pm 5.1$ hours. Group 2- $21.6 \pm 6.3$ hours $(p=0.07)$ and Group 3- $24.6 \pm 5.7$ hours $(p<0.001$, $1 \times 3 ; p=0.002,2 \times 3)$. B. Prevalence of delayed graft function according groups: Grupo $1-64.6 \%$, Grupo $2-68.4 \%(p=0.97)$ e Grupo $3-82.1 \%(p=0.50,1 \times 3$; $\mathrm{p}=0.60,2 \times 3)$

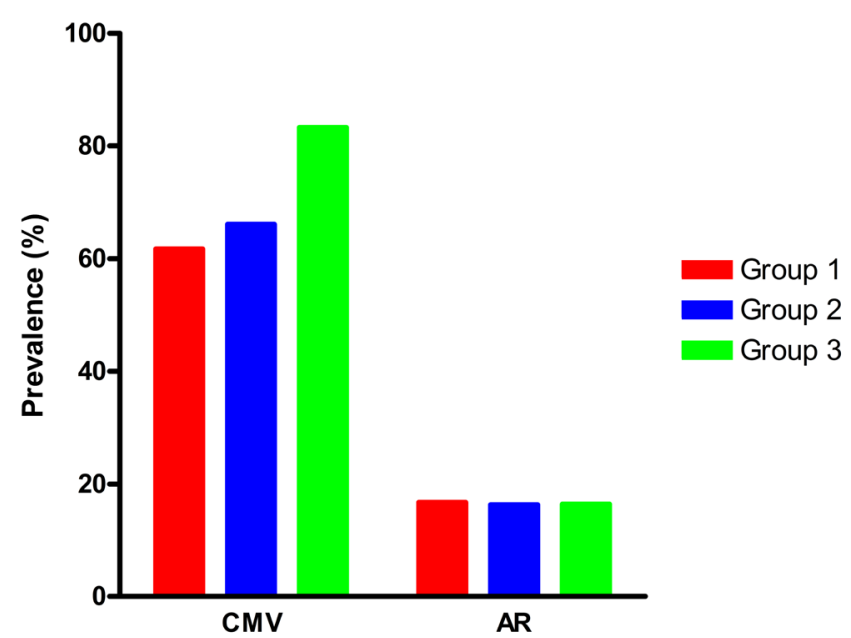

Figure 4. Cytomegalovirus (CMV) infection: Group 1- 61.7\%; Group 2- $66.1 \%$ $(p=0.85)$ and Group 3- 83.3\% ( $p=0.37,1$ vs. $3 ; p=0.48,2$ vs. 3). Acute rejection (AR): Group 1- 16.7\%; Group 2- $16.3 \%(p=0.99)$; Group 3- $16.4 \%(p=0.88,1$ vs. $3 ; p=0.88,2$ vs. 3 )

(med-57 days [34-179]), with a reduction to $56.8 \pm 63.1$ days (med-42 [10-410]) in Group $2(\mathrm{p}=0.005$, Group 1 versus Group 2) and to $47.1 \pm 22.5$ days (med-41 [18$115]$ ) in Group 3 ( $\mathrm{p}<0.001$, Group 1 versus Group 3; $p=0.55$, Group 2 versus Group 3). As shown in Figure $5 \mathrm{~B}$, the viral load detected by the number of cells infected by the virus using antigenemia was similar in all three groups: Group 1: $61.1 \pm 66.5$ cells (med-23 [2-243]); Group 2: $56.91 \pm 118.8$ cells (med-20 [3-680]) $(\mathrm{p}=0.25$, Group 1 versus Group 2); Group 3: 61.9 \pm 103.9 (med-15 [2-480]) ( $\mathrm{p}=0.19$, Group 1 versus Group 3; $\mathrm{p}=0.76$, Group 2 versus Group 3).

\section{Survival and renal graft function}

Renal graft survival one year after transplantation, not censored for deaths, was similar in all three groups (Figure 6): $89.6 \%, 92.9 \%$ and $91.0 \%$, in Groups 1, 2 

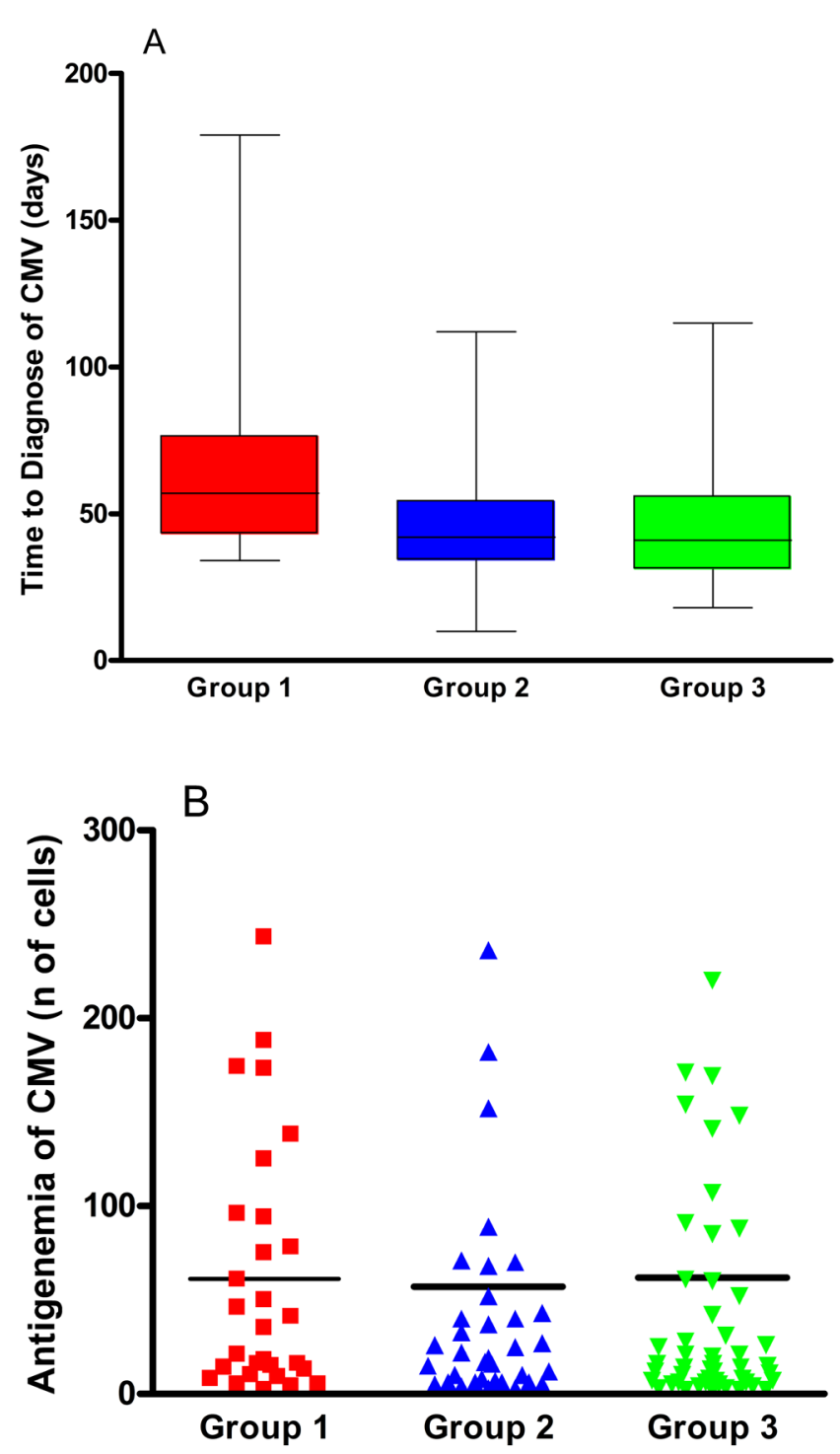

Figure 5. A - Time after transplant for diagnosis of cytomegalovirus (CMV) infection: Group 1- $64.3 \pm 28.5$ days, Group 2- $56.8 \pm 63.1$ days $(p=0.005)$ and Group 3- $47.1 \pm 22.5$ days $(p<0.001,1 \times 3 ; p=0.55,2 \times 3)$. B - Antigenemia to Cytomegalovirus (CMV): group $1-61.1 \pm 66.5$ cells, group $2-56.9 \pm 118.8$ cells $(p=0.25)$ and group $3-61.9 \pm 103.9$ cells $(p=0.19,1 \times 3 ; p=0.76,2 \times 3)$.

e 3, respectively. Of the patients whose graft was still functioning by the end of the first year, renal graft function during this period, as shown in Figure 7, was better in Group 3, where it attained a mean value of $71.2 \pm 18.4 \mathrm{~mL} / \mathrm{min}$, compared to $67.0 \pm 18.4 \mathrm{~mL} / \mathrm{min}$ in Group 2 ( $\mathrm{p}=0.06$, Group 3 versus Group 2) and 57.0 $\pm 20.0 \mathrm{~mL} / \mathrm{min}$ in Group 1 ( $\mathrm{p}<0.001$, Group 1 versus Group 3; $\mathrm{p}=0.008$, Group 1 versus Group 2).

\section{Cost of thymoglobulin}

As expected, there was a substantial reduction in the cost of thymoglobulin (Table 2) as the induction

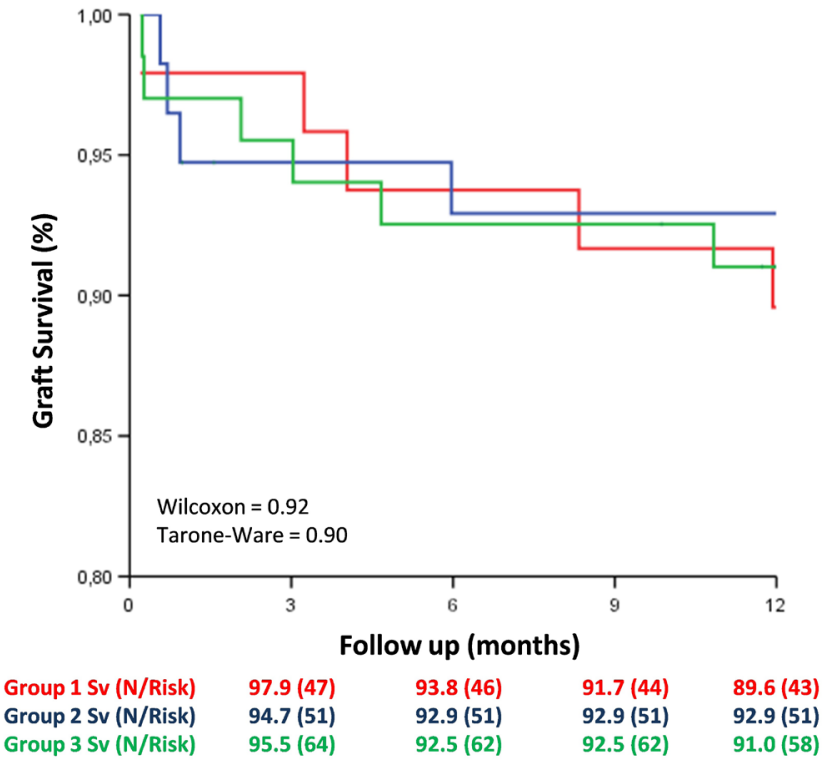

Figure 6. Renal graft survival

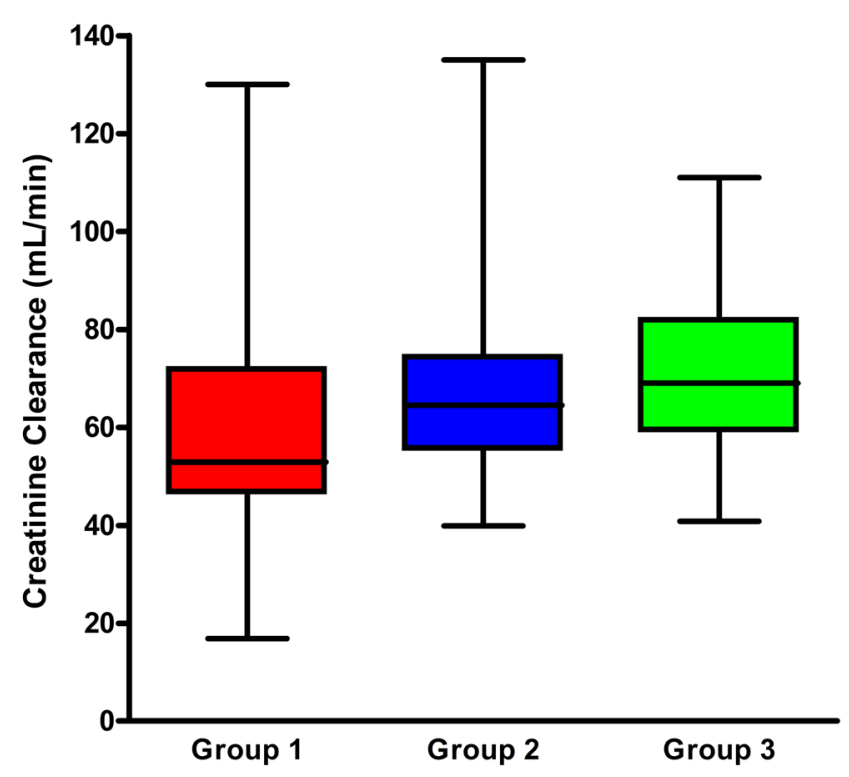

Figure 7. Group 1- $57.0 \pm 20.0 \mathrm{~mL} / \mathrm{min}$; Group 2- $67.0 \pm 18.4 \mathrm{~mL} / \mathrm{min}(p=0.008)$; Group 3- $71.2 \pm 18.4 \mathrm{~mL} / \mathrm{min}(p<0.001,1 \times 3 ; p=0.06,1 \times 2)$.

protocol was modified over time. As reported earlier, Group 1 used a mean number of $9.0 \pm 3.8$ doses, at an estimated mean cost of US\$ 7,925.87 $\pm 4,493.83$ (med- 7,576.02 [1,681.96-21,024.50]). Group 2, in turn, used a total of $4.9 \pm 1.5$ doses, with an estimated cost of US\$ 4,409.87 $\pm 1,772.71$ (med-4,060.73 [1,547.40$10,308.01])(\mathrm{p}<0.001$, Group 1 versus Group 2). Group 3 used $3.9 \pm 0.8$ doses, with an estimated cost of US\$ $3,564.76 \pm 1,046.76$ (med-3,485.56 [468.55-5,406.30]) ( $\mathrm{p}<0.001$, Group 1 versus Group 3; $\mathrm{p}=0.006$, Group 2 versus Group 3). 
Table 2. Cost estimate per group of patients

\begin{tabular}{lccc}
\hline Variable & Group 1 & Group 2 & Group 3 \\
\hline Mean \pm SD & $7,925.87 \pm 4,493.83$ & $4,409.87 \pm 1,772.71$ & $3,564.76 \pm 1,046.76$ \\
Median & $7,567.02$ & $4,060.73$ & $3,485.56$ \\
Min-Max & $1,681.96-21,024.50$ & $1,547.40-10,308.01$ & $468.55-5,406.30$ \\
\hline
\end{tabular}

SD: standard deviation; Min: minimum value; Max: maximum value.

$p<0.001$ (Group 1 versus Group 2); $p<0.001$ (Group 1 versus Group 3); $p=0.006$ (Group 2 versus Group 2) Values in US dollars

\section{DISCUSSION}

Immunological induction with antilymphocyte antibodies has been widely used as a strategy for reducing the risk of $\mathrm{AR}$ in renal transplantation. Lymphocyte-depleting polyclonal antibodies, such as thymoglobulin, are related to a lower incidence of severe rejection in high-risk patients as compared to non-lymphocyte-depleting monoclonal antibodies, such as basilixmab ${ }^{(12)}$. Among the lymphocytedepleting polyclonal antibodies, thymoglobulin is the most effective, without presenting an increase in side effects, when compared to ATGAM or antilymphocyte antibodies ${ }^{(18)}$. Therefore, immunological induction with thymoglobulin has been considered one of the most adequate strategies for reducing the risk of $\mathrm{AR}$ and for a better long-term survival in high-risk patients. Patients who are candidates for a kidney transplantation and have a history of sensitization, especially those submitted to a retransplantation, are considered highrisk patients; however, IRI has also been implicated as a triggering factor for cellular immune response, with the consequent risk of rejection and poorer graft survival $^{(6,19)}$. It has already been demonstrated that the use of thymoglobulin before reperfusion is associated with a reduction in the incidence of DGF, as well as with a faster recovery of renal function ${ }^{(15)}$. In this context, patients submitted to kidney transplantation with a high risk of DGF benefited from the use of thymoglobulin, with a reduction of adverse clinical events.

The Transplantation Service involved in this study started the use of thymoglobulin in 2002 for all patients receiving a kidney from a deceased donor, not only aiming to reduce the risk of $A R$, but also with the purpose of reducing the effects of IRI. During the evaluated period, there was a significant increase in CIT, bringing about a proportional increase in the prevalence of DGF, which reached $80 \%$ in the most recent period. Although a reduction in the prevalence of DGF was expected with the use of the intraoperative dose of thymoglobulin ${ }^{(15)}$, some authors stated that, in transplantations performed with a very high CIT, especially over 24 hours, very little strategies are effective for reducing the prevalence of $\mathrm{DGF}^{(12)}$. Nevertheless, even with the increase in CIT and the DGF rate, no increase in the incidence of AR or any impact on the renal graft function was observed in up to one year follow-up, suggesting that, even without reducing the risk of DGF, the use of thymoglobulin may be associated with protection from the late effects of IRI on the renal $\operatorname{graft}^{(20)}$.

Although many clinical trials demonstrated that immunological induction with thymoglobulin is safe and effective ${ }^{(12-16)}$, the best regimen with regard to number of doses, frequency and accumulated antibody dose has not been established yet. A great part of the experience with the use of antibodies in kidney transplantation was acquired by its use for the treatment of AR, which, in some protocols, reached a total of 14 doses. Ever since, several studies compared a number of induction protocols, in order to define how many doses or how many days of treatment would be necessary to establish a safety profile for the use of thymoglobulin for immunological induction $^{(13,14)}$. In this study, in Group 1, a protocol extrapolating from the one indicated for the treatment of AR was used, allowing the use of up to 14 doses, provided the patients remained in DGF. As of 2004, after analyzing the results obtained in a first phase, it was demonstrated that the use of 7 doses was as safe as the use of up to $14 \operatorname{doses}^{(21)}$. Later on, some published clinical trials comparing thymoglobulin induction protocols confirmed that the use of five to seven doses was safe and effective. Recently, new published data have indicated that an accumulated thymoglobulin dose between 4.0 e $7.0 \mathrm{mg} / \mathrm{kg}$ warranted excellent results, regardless of the frequency of antibody administration ${ }^{(12-}$ 16). In the last period analyzed, defined as Group 3, four doses were used, amounting to an accumulated dose of $4.5 \mathrm{mg} / \mathrm{kg}$. The results presented here demonstrate that the reduction of the total number of doses to up to four thymoglobulin doses did not increase the prevalence of AR, nor did it alter the survival of the graft by the end of one-year follow-up. Brennan et al., in a study that used 5 to 7 days of thymoglobulin induction, found an incidence of AR confirmed by biopsy (15.6\%) similar to that found in Group $3^{(12)}$. The increase in the prevalence of DGF was attributed to the progressive increase in CIT and not to the reduction in the number of antibody doses; there was, however, no significant increase in the time the patient remained in DGF.

An interesting observation of this study was the better function of the renal graft by the end of one 
year in Group 3. The study design does not allow attributing this improvement to the modification of the induction protocol, especially because it is not possible to compare the several variables that may interfere in the progression of the renal function with the period when the transplantation was performed. However, an important clinical study using thymoglobulin in highrisk patients demonstrated that the induction associated to the use of tacrolimus at low doses was the regimen associated with the best graft function, as compared to tacrolimus at the usual doses or sirolimus ${ }^{(22)}$. Recently, the Transplantation Service of the Hospital Israelita Albert Einstein adopted the strategy of using lower doses of calcineurin inhibitor, aiming at intermediary levels. Another difficulty in comparing the renal function results of each of the groups evaluated here with those of other studies is that only a few of them defined renal function as a primary outcome ${ }^{(23)}$.

Another important outcome evaluated in this study was CMV infection. The use of lymphocyte-depleting antibodies is clearly associated with an increase in the risk of CMV infection. Patients using lymphocytedepleting antibodies, both for immunological induction and for treatment of AR, may present a CMV viremia prevalence of up to $80 \%{ }^{(17)}$. Therefore, whenever the choice to use these antibodies is made, one of the two risk-reduction strategies for cytomegalic inclusion disease should be adopted: preemptive treatment or prophylaxis $^{(24)}$. In the protocol under discussion, the strategy adopted was preemptive treatment, which does not reduce the incidence of viremia, but is as effective as prophylaxis to reduce the risk of developing the disease. Although not mentioned in the results of the present work, the prevalence of invasive disease was of $6 \%$ to $8 \%$, which is similar to the results of other studies, and there were no differences among the groups. Contrary to expectations, patients receiving a lower accumulated dose of thymoglobulin (Group 3) had a higher prevalence of viremia, besides an earlier diagnosis. A partial analysis of the impact of immunosuppression on the prevalence of CMV was made in a cohort of patients included in this study and demonstrated that tacrolimus was related to a two-fold increase in viremia risk, as compared to cyclosporin ${ }^{(25)}$. All patients of Group 3 used tacrolimus, while it was given to $78.9 \%$ in Group 2 and to only $14.6 \%$ in Group 1 . This may have been one of the reasons why there was a significant increase in the prevalence of CMV among the patients who received a smaller number of thymoglobulin doses.

In populations of patients at high risk of DGF and $\mathrm{AR}$, the use of immunological induction is an effective and safe strategy for reducing the short- and long-term adverse effects ${ }^{(12-16)}$. The analysis presented here demonstrates that adjusting the thymoglobulin induction protocol to a reduced number of doses, with an accumulated dose of $4.5 \mathrm{mg} / \mathrm{kg}$ did not change the prevalence of AR or the survival of the graft in oneyear follow-up. In spite of the difference in the type of calcineurin inhibitor used (cyclosporin or tacrolimus), it can be stated that minimizing the number of thymoglobulin doses in association with the use of tacrolimus is safe and effective in this kind of patient. Besides observing a substantial improvement in renal graft function after one year, which, as already discussed, cannot be attributed to the modification made in the induction protocol, an undisputable benefit that is also directly related to the appropriateness of number of thymoglobulin doses is the cost of transplantation. Although, in the long run, renal replacement therapy is cheaper than dialysis, the expenses during the first year after transplantation are still substantially higher, especially due to cost of transplantation itself( ${ }^{(26)}$. Regarding the use of immunological induction, it was demonstrated here that there is a significant reduction in the cost of the initial treatment, evaluated by estimating the expense with thymoglobulin, which can be considered an additional benefit.

\section{REFERÊNCIAS}

1. Starzl TE, Marchioro TL, Hutchinson A, Porter KA, Cerilli GJ, Brettschneider $\mathrm{L}$. The clinical use of antilymphocyte globulin in renal homotransplantations. Transplantation. 1967;5(4):1100-5.

2. Mueller TF. Thymoglobulin: an immunologic overview. Curr Opin Organ Transplant. 2003;8:305-12.

3 Lebranchu Y, Bridoux F, Büchler, M Le Meur Y, Etienne I, Toupance 0, et al. Immunoprophylaxis with Basiliximab compared with Antithymocyte Globulin in renal transplant patients receiving MMF-containg triple therapy. Am J Transplant. 2002;2(1):48-56.

4. Chertow GM, Milford EL, Mackenzie HS, Brenner BM. Antigenindependent determinants of cadaveric kidney transplant failure. JAMA. 1996;276(21):1732-6.

5. Cecka JM, Cho YW, Terasaki PI. Analyses of the UNOS Scientific Renal Transplant Registry at three years--early events affecting transplant success. Transplantation. 1992;53(1):59-64.

6. Ojo A0, Wolf RA, Held PJ, Prot FK, Schmouder RL. Delayed graft function: risk factors and implications for renal allograft survival. Transplantation. 1997;63(7):968-74.

7. Lemay S, Rabb H, Postler G, Singh AK. Prominent and sustained up-regulation of gp130-signalin cytokines and the chemokine MPI-2 in murine renal ischemiareperfusion injury. Transplantation. 2000;69(5):959-63.

8. Shokes DA, Cecka JM. Deleterious effects of delayed graft function in cadaveric renal transplant recipients independent of acute rejection. Transplantation. 1998;66(12):1697-701.

9. Burne MJ, Daniels F, El Ghandour A, Mauiyyedi S, Colvin RB, ODonnell MP, et al. Identification of the CD4+ T Cell as a major pathogenic factor in ischemic acute renal failure. J Clin Invest. 2001;108(9):1283-90.

10. Yokota N, Daniles F, Crosson J, Rabb H. Protective effect of T cell depletion in murine renal ischemia-reperfusion injury. Transplantation. 2002;74(6): 759-63. 
11. Woodside KJ, Hu M, Meng T, Hunter GC, Sower LE, Daller JA. Differential effects of interleukin-2 blokade on apoptosis in naive and active human lymphocytes. Transplantation. 2003;75(10):1631-5.

12. Brennan DC, Daller JA, Lake KD, Cibrik D, Del Castillo DD; Thymoglobulin Induction Study Group. Rabbit antithymocyte globulin versus basiliximab in renal transplantation. N Eng J Med. 2006;355(19):1967-77.

13. Agha IA, Rueda J, Alvarez A, Singer GG, Miller BW, Flavin K, et al. Short course induction immunosuppression with Thymoglobulin for renal transplant recipients. Transplantation. 2002;73(3):473-5.

14. Stevens RB, Mercer DF, Grant WJ, Freifeld AG, Lane JT, Groggel GC, et al. Randomizes trial of single-dose versus divided dose rabbit anti-thymocyte globulin induction in renal transplantation: an interim report. Transplantation. 2008;85(10):1391-9.

15. Goggins WC, Pascual MA, Powelson JA, Magee C, Tolkoff-Rubin N, Farrell $\mathrm{ML}$, et al. A prospective, randomized, clinical trial of intraoperative versus postoperative Thymoglobulin in adult cadaveric renal transplant recipients. Transplantation.2003;76(5):798-802.

16. Peddi VR, Bryant M, Roy-Chaudhury P, Woodle S, First MR. Safety, efficacy, and cost analysis of Thymoglobulin induction therapy with intermittent dosing based on CD3 + lymphocyte counts in kidney and kidney-pancreas transplant recipients. Transplantation. 2002;73(9):1514-8.

17. Ozaki KS, Pestana JOM, Granato CFH, Pacheco-Silva A, Camargo LFA. Sequential cytomegalovirus antigenemia monitoring in kidney transplant patients treated with antilymphocyte antibodies. Transplant Infect Dis. 2004;6(2):63-8.

18. Hardinger KL, Schnitzler MA, Miller B, Lowell JA, Shenoy S, Koch MJ, et al. Five-years follow up of Thymoglobulin versus ATGAM induction in adult renal transplantation. Transplantation. 2004;78(1):136-41.
19. Goes N, Urmson J, Ramassar V, Halloran PF. Ischemic acute tubular necrosis induces an extensive local cytokine response. Evidence for induction of interferon-gamma, transforming growth factor-beta 1, granulocytemacrophage colony-stimulating factor, interleukin-2, and interleukin-10. Transplantation. 1995;59(4):565-72.

20. Moura LR, Pereira MG, Durão M, Tonato EJ, Matos AC, Wroclawski ER, et al. Thymoglobulin as an induction therapy: protection against ischemia and reperfusion injury. Einstein. 2006;4(4):315-20.

21. Requião-Moura LR, Durão MS, Tonato EJ, Pereira MG, Wroclawski ER, Matos $A C$, et al. Effect of Thymoglobulin in graft survival and function 1 year after kidney transplantation using deceased donors. Transplant Proc. 2006;38(6):1895-7.

22. Ekberg $H$, Tedesco-Silva $H$, Demirbas $A$, Vítko $S$, Nashan B, Gürkan $A$, Margreiter R, Hugo C, Grinyó JM, Frei U, Vanrenterghem Y, Daloze P, Halloran PF; ELITE-Symphony Study. Reduced exposure to calcineurin inhibitors in renal transplantation. N Eng J Med. 2007;357(25):2562-75.

23. Demirbas A, Hugo C, Grinyó J, Frei U, Gürkan A, Marcén R, et al. Low toxicity regimens in renal transplantation: a country subset analysis of the Symphony study. Transplant International. 2009;22(12):1172-81.

24. Kalil AC, Levitsky J, Lyden E, Stoner J, Freifeld A. Meta-analysis: the efficacy of strategies to prevent organ disease by Cytomegalovirus in solid organ transplant recipients. Ann Intern Med. 2005;143(12):870-80.

25. Requião-Moura LR, Arruda EF, Tonato EJ, Chinen R, Durão MS, PachecoSilva A. Effect of Cytomegalovirus Viremia in Early Tubular Proximal Injury and Late Renal Graft Function. Am J Transplant. 2010;10:332 [abstract].

26. Zelmer JL. The economic burden of end-stage renal disease in Canada. Kidney Internat. 2007;72(1):1122-9. doi:10.1038/sj.ki.5002459. 